\title{
Effects of soil fertility on the persistence of dryland cocksfoot and tall fescue pastures
}

\author{
D.R. SMITH ${ }^{1}$, T.J. FRASER ${ }^{2}$, C.A. MOFFAT ${ }^{1}$ and M.J. DALY ${ }^{2}$ \\ ${ }^{1}$ AgResearch, Poukawa Research Station, PO Box 8144, Havelock North \\ ${ }^{2}$ AgResearch, Lincoln Research Centre, PO Box 60, Lincoln
}

\section{Abstract}

The persistence of pastures sown with tall fescue, cocksfoot or mixtures of the two species was evaluated by tiller core measurements on 106 paddocks that had been sown in 1989 or 1991 on dryland east coast sheep/beef farms. In both North and South Island paddocks, cocksfoot was the dominant grass in mixtures of tall fescue and cocksfoot. Tall fescue presence was usually much lower than that of ryegrass and other unsown grasses, regardless of sowing mixture. High levels of cocksfoot were associated with low levels of ryegress, browntop and other perennial grasses. North Island paddocks had higher P levels (Olsen $\mathrm{P}=25$ ) than South Island paddocks (Olsen $\mathrm{P}=21$ ) but had lower levels of clover (32\%) and higher levels of browntop (26\%) than South Island paddocks (52\% clover, $13 \%$ browntop). In North Island paddocks sown with cocksfoot, there were weak, negative associations of white clover with fertiliser $\mathrm{N}$ inputs $(\mathrm{r}=-0.45)$ and soil $\mathrm{P}$ levels $(\mathrm{r}=$ $0.41)$. These effects of $\mathrm{P}$ and $\mathrm{N}$ on clover appeared to be owing to increased cocksfoot dominance at high fertility. In the North Island, the best white clover presence was found in pastures that were low in cocksfoot but high in ryegrass, browntop and other unsown perennial grasses. In the South Island there was no significant association of clover with soil test levels or fertiliser history. Comparison of 1996 measurements made on North Island paddocks with 1991 measurements on the same paddocks indicated that establishment effects could have long-term effects on the persistence of tall fescue and cocksfoot. Inclusion of cocksfoot in the seed mix reduced tall fescue persistence. High levels of perennial ryegrass at establishment were also associated with poor tall fescue persistence. These effects appeared to be more important than soil fertility constraints in reducing tall fescue persistence. The presence of other vigorous grasses, such as ryegrass, during establishment may also reduce or delay cocksfoot dominance and thus improve white clover persistence.

Keywords: cocksfoot, dryland, pasture persistence, soil fertility, tall fescue

\section{Introduction}

Cocksfoot and tall fescue based pastures can be valuable alternatives to perennial ryegrass in areas where frequent droughts reduce ryegrass production and quality over summer and autumn. Because of their drought and insect tolerance, they are generally expected to persist longer than perennial ryegrass. However, tall fescue pastures often revert to unsown volunteer grasses after a few years. For cocksfoot, persistence of cocksfoot itself does not appear to be a problem. Rather, cocksfoot pastures maintain high cocksfoot levels, but companion legume species often disappear and pasture quality deteriorates.

In New Zealand the role of phosphate and sulphur fertilisers in increasing the clover and ryegrass content of pastures has been well researched (e.g., Ledgard \& Brier 1993). Nitrogen fertiliser application usually reduces clover abundance (Morton et al. 1993). In contrast to the extensive knowledge for ryegrass-based pastures, knowledge about other pasture types is relatively limited, mainly observational rather than scientific. Compared with ryegrass, cocksfoot is considered to require lower and tall fescue higher soil fertility.

This study looked at the relationship between the persistence of tall fescue- and cocksfoot-based pastures and soil fertility in dryland east coast environments. The study draws on a population of paddocks established specifically to demonstrate the benefits of these grasses in drought-prone areas.

\section{Methods}

The 106 paddocks measured in this survey were sown as part of the 1988/89 South Island Drought Recovery Programme (Milne \& Fraser 1990) or the 1990/91 North Island Recovery Programme (Milne et al. 1993). A total of 73 properties (47 South Island, 26 North Island) were represented with 1-3 paddocks per property. The 69 South Island paddocks were sown in autumn 1989 and included 48 in South Canterbury and 31 in coastal North Otago. The 37 North Island paddocks were sown in autumn 1991 and included five in the Gisborne District and 32 in Hawke's Bay. These North Island paddocks had previously been a part of study of the establishment of tall fescue and cocksfoot (Smith et al. 1993). All 
paddocks were sown with the assistance of DSIR (now AgResearch) Grassline ${ }^{\circledR}$ consultants who provided advice on seed mixtures, pre-sowing preparation and paddock management. Seed mixtures used in these paddocks are summarised in Table 1 . Nine of the tall fescue/cocksfoot mixtures also include Puna chicory in the seed mixture at an average rate of $1.5 \mathrm{~kg} / \mathrm{ha}$.

Table 1 Seed mixtures of paddocks included in persistence survey.

\begin{tabular}{|c|c|c|c|c|c|c|}
\hline \multirow[b]{2}{*}{ Pasture type } & \multirow{2}{*}{\multicolumn{2}{|c|}{$\begin{array}{c}\text { Tall Cocksfoot } \\
\text { fescue }\end{array}$}} & \multicolumn{2}{|c|}{ Seed rate $(\mathrm{kg} / \mathrm{ha})$} & \multirow[b]{2}{*}{$\begin{array}{l}\text { Red } \\
\text { clover }\end{array}$} & \multirow[b]{2}{*}{$\begin{array}{c}\text { Sub } \\
\text { clover }\end{array}$} \\
\hline & & & Phalaris & $\begin{array}{l}\text { White } \\
\text { clover }\end{array}$ & & \\
\hline \multicolumn{7}{|c|}{ Tall fescue $(n=14)$} \\
\hline Mean & 19.7 & 0 & 0 & 2.6 & 2.9 & 1.0 \\
\hline Range & $16-20$ & & & $2-3$ & $0-6$ & $0-5$ \\
\hline \multicolumn{7}{|c|}{ Tall fescue/cocksfoot $(n=78)$} \\
\hline Mean & 14.3 & 4.1 & 0.9 & 2.8 & 1.3 & 0.7 \\
\hline Range & $8-18$ & $2-7$ & $0-3$ & $1-3.6$ & $0-5$ & $0-5$ \\
\hline \multicolumn{7}{|c|}{ Cocksfoot $(n=14)$} \\
\hline Mean & 0 & 7.8 & 2 & 2.8 & 1.4 & 0.6 \\
\hline Range & & $5-12$ & $0-4$ & $2-3$ & $0-5$ & $0-6$ \\
\hline
\end{tabular}

Twenty-three of the 32 North Island paddocks received fertiliser $\mathrm{N}$ at least once over the 1993-1996 period. Most of the fertiliser $\mathrm{N}$ applied in the North Island was in late winter to mid spring $(69 \%$ between July and October) or in March-April (21\%). The average rate of $\mathrm{N}$ applied per application was $28 \mathrm{~kg} / \mathrm{ha}$. Of the total $\mathrm{N}$ applied, $81 \%$ was in the form of DAP or DAPbased products. The 15 South Island paddocks that received $\mathrm{N}$ were mainly August or September applications, again with $80 \%$ applied as DAP-based products.

\section{Soil test levels}

Average Olsen $\mathrm{P}$ levels were significantly higher in North Island survey paddocks than in South Island paddocks (Table 3 ). K levels were higher in South Island paddocks.
Farmers participating in the survey were asked to complete a questionnaire to provide information on fertiliser inputs over the period July 1993 to September 1996. These responses were used to calculate total input of major fertiliser elements (N, P, S, and K).

Paddocks were sampled between 22/10/96 and 30/ 11/96. Forty-eight turf cores (Mitchell \& Glenday 1958) were collected from each of two sampling areas. Cores were $50 \mathrm{~mm}$ in diameter and about $50 \mathrm{~mm}$ deep. Each core was pulled apart in the laboratory to determine presence of sown and unsown species.

Ten soil cores, $75 \mathrm{~mm}$ deep were collected from each sampling area and bulked on a paddock basis ( 20 soil cores). These were analysed for Olsen P organic sulphur (OS), $\mathrm{K}, \mathrm{Ca}, \mathrm{Na}, \mathrm{Mg}$ and $\mathrm{pH}$.

\section{Results and Discussion}

\section{Fertiliser inputs}

Fertiliser inputs were significantly higher $(\mathrm{P}<0.05)$ in North Island survey paddocks than in the South Island, particularly for $\mathrm{P}$ and $\mathrm{N}$ (Table 2). There was no significant difference in fertiliser inputs between cocksfoot pasture, tall fescue pastures or cocksfoot/ fescue mixtures.

Table 2 Average annual inputs of fertiliser N, P, S and K over the period July 1993 to June 1996.

\begin{tabular}{lcccr}
\hline & Mean annual & ertiliser application $(\mathrm{kg} / \mathrm{ha} / \mathrm{yr})$ \\
& $\mathrm{N}$ & $\mathrm{P}$ & $\mathrm{S}$ & $\mathrm{K}$ \\
\hline North Island $(\mathrm{n}=32)$ & 18.6 & 29.3 & 28.4 & 4.3 \\
South Island $(\mathrm{n}=67)$ & 2.3 & 11.6 & 23.0 & 0.5 \\
Range & $0-66$ & $0-84$ & $0-96$ & $0-29$ \\
\hline
\end{tabular}

Table 3 Average soil test levels in survey paddocks in 1996.

\begin{tabular}{lcccc}
\hline & -------- & 1996 soil test level & \\
& $P$ & OS & K & pH \\
\hline North Island $(n=32)$ & 25 & 8 & 9 & 5.8 \\
South Island $(n=69)$ & 21 & 7 & 14 & 5.9 \\
Range & $5-55$ & $2-40$ & $3-59$ & $5.3-7.4$ \\
\hline
\end{tabular}

There was no significant association between soil test levels and fertiliser inputs over the 1993-1996 period, with one major exception. North Island paddocks with high $\mathrm{P}$ levels tended to receive more fertiliser $\mathrm{N}$ than paddocks with low $\mathrm{P}$ levels $(\mathrm{r}=0.64, \mathrm{P}<0.001)$. This association was probably owing to the regular use of DAPbased products on many of the North Island paddocks. The lack of association of soil $\mathrm{P}$ with fertiliser $\mathrm{P}$ inputs is probably owing to the application of $\mathrm{P}$ fertiliser mainly to maintain current status rather than as capital dressings.

\section{Species presence}

In both North and South Island paddocks, cocksfoot was the dominant grass in mixtures of tall fescue and cocksfoot. Tall fescue presence was usually much lower than that of ryegrass and other unsown grasses, regardless of sowing mixture.

South Island paddocks had significantly more white clover than did North Island paddocks. The mean level of white clover present in North Island paddocks was similar to that reported by Morton et al. (1993) for Wairarapa ryegrass pastures $(32 \%$ in pastures receiving regular N fertiliser). Korte et al. (1991) reported slightly higher average levels of white clover in their survey of East Coast North Island pastures $(49 \%$ in ryegrass 
Table 4 Presence of different species and species categories on tiller cores.

\begin{tabular}{|c|c|c|c|c|c|c|c|c|c|}
\hline Paddock type & $\mathrm{n}$ & $\begin{array}{c}\text { Tall } \\
\text { fescue }\end{array}$ & Cocksfoot & $\begin{array}{l}\text { Perce } \\
\text { Phalaris }\end{array}$ & $\begin{array}{c}\text { tage of core } \\
\text { Ryegrass }\end{array}$ & $\begin{array}{l}\text { ontaining sp } \\
\text { Browntop }\end{array}$ & $\begin{array}{l}\text { Other } \\
\text { per. grass }\end{array}$ & $\begin{array}{l}\text { Ann. } \\
\text { grass }\end{array}$ & $\begin{array}{l}\text { White } \\
\text { clover }\end{array}$ \\
\hline $\begin{array}{l}\text { Tall fescue } \\
\text { NI mean } \\
\text { SI mean } \\
\text { Range }\end{array}$ & $\begin{array}{c}2 \\
12\end{array}$ & $\begin{array}{c}56 \\
29 \\
10-65\end{array}$ & $\begin{array}{c}0 \\
3 \\
0-16\end{array}$ & $\begin{array}{c}0 \\
0 \\
0-2\end{array}$ & $\begin{array}{c}24 \\
49 \\
6-97\end{array}$ & $\begin{array}{c}30 \\
22 \\
0-47\end{array}$ & $\begin{array}{c}63 \\
30 \\
4-79\end{array}$ & $\begin{array}{c}2 \\
21 \\
1-45\end{array}$ & $\begin{array}{c}33 \\
51 \\
4-78\end{array}$ \\
\hline $\begin{array}{l}\text { TF/CF mixtures } \\
\text { NI mean } \\
\text { SI mean } \\
\text { Range }\end{array}$ & $\begin{array}{l}28 \\
50\end{array}$ & $\begin{array}{c}10 \\
13 \\
0-40\end{array}$ & $\begin{array}{c}44 \\
55 \\
1-92\end{array}$ & $\begin{array}{c}3 \\
2 \\
0-22\end{array}$ & $\begin{array}{c}26 \\
23 \\
1-71\end{array}$ & $\begin{array}{c}26 \\
11 \\
0-60\end{array}$ & $\begin{array}{c}25 \\
18 \\
0-85\end{array}$ & $\begin{array}{c}12 \\
22 \\
0-62\end{array}$ & $\begin{array}{c}32 \\
52 \\
0-96\end{array}$ \\
\hline $\begin{array}{l}\text { Cocksfoot } \\
\text { NI mean } \\
\text { SI mean } \\
\text { Range }\end{array}$ & $\begin{array}{l}7 \\
7\end{array}$ & $\begin{array}{l}0 \\
0\end{array}$ & $\begin{array}{c}63 \\
65 \\
31-88\end{array}$ & $\begin{array}{c}5 \\
4 \\
0-18\end{array}$ & $\begin{array}{c}21 \\
11 \\
1-38\end{array}$ & $\begin{array}{c}24 \\
9 \\
0-77\end{array}$ & $\begin{array}{c}23 \\
15 \\
0-76\end{array}$ & $\begin{array}{c}7 \\
12 \\
1-31\end{array}$ & $\begin{array}{c}39 \\
50 \\
3-66\end{array}$ \\
\hline $\begin{array}{l}\text { All paddocks }{ }^{1} \\
\text { NI mean } \\
\text { SI mean }\end{array}$ & $\begin{array}{l}37 \\
69\end{array}$ & $\begin{array}{l}15 \\
15\end{array}$ & $\begin{array}{l}49 \\
55\end{array}$ & $\begin{array}{l}5 \\
3\end{array}$ & $\begin{array}{l}27 \\
25\end{array}$ & $\begin{array}{l}26 \\
13\end{array}$ & $\begin{array}{l}27 \\
19\end{array}$ & $\begin{array}{l}11 \\
21\end{array}$ & $\begin{array}{l}32 \\
52\end{array}$ \\
\hline Significance & & ns & 0.06 & ns & ns & 0.001 & 0.02 & 0.001 & 0.001 \\
\hline
\end{tabular}

Table 5 Correlations between species. Significance level of correlation coefficient is given as the second line in each cell.

\begin{tabular}{|c|c|c|c|c|c|c|c|c|}
\hline & White clover & Ryegrass & Browntop & $\begin{array}{l}\text { Other } \\
\text { per. grass }\end{array}$ & $\begin{array}{l}\text { Annual. } \\
\text { grass }\end{array}$ & $\begin{array}{l}\text { Sub } \\
\text { clover }\end{array}$ & $\begin{array}{l}\text { Annual } \\
\text { legumes }\end{array}$ & Weeds \\
\hline \multicolumn{9}{|l|}{ North Island } \\
\hline Cocksfoot & $\begin{array}{r}-0.47 \\
0.0001\end{array}$ & $\begin{array}{r}-0.58 \\
0.0001\end{array}$ & $\begin{array}{l}-0.34 \\
0.005\end{array}$ & $\begin{array}{l}-0.34 \\
0.005\end{array}$ & $\begin{array}{r}-0.07 \\
\text { ns }\end{array}$ & $\begin{array}{r}0.05 \\
\text { ns }\end{array}$ & $\begin{array}{r}-0.10 \\
n s\end{array}$ & $\begin{array}{r}0.03 \\
\mathrm{~ns}\end{array}$ \\
\hline Tall fescue & $\begin{array}{r}0.04 \\
\mathrm{~ns}\end{array}$ & $\begin{array}{r}-0.19 \\
n s\end{array}$ & $\begin{array}{r}0.10 \\
\mathrm{~ns}\end{array}$ & $\begin{array}{r}0.10 \\
\mathrm{~ns}\end{array}$ & $\begin{array}{r}-0.03 \\
n s\end{array}$ & $\begin{array}{r}-0.11 \\
n s\end{array}$ & $\begin{array}{r}-0.13 \\
n s\end{array}$ & $\begin{array}{r}-0.02 \\
n s\end{array}$ \\
\hline $\begin{array}{l}\text { White } \\
\text { clover }\end{array}$ & & $\begin{array}{r}0.43 \\
0.0002\end{array}$ & $\begin{array}{r}0.39 \\
0.001\end{array}$ & $\begin{array}{r}0.45 \\
0.0001\end{array}$ & $\begin{array}{r}0.00 \\
\mathrm{~ns}\end{array}$ & $\begin{array}{r}-0.09 \\
n s\end{array}$ & $\begin{array}{r}0.01 \\
\mathrm{~ns}\end{array}$ & $\begin{array}{r}-0.02 \\
n s\end{array}$ \\
\hline $\begin{array}{l}\text { South Island } \\
\text { Cocksfoot }\end{array}$ & $\begin{array}{r}0.08 \\
\mathrm{~ns}\end{array}$ & $\begin{array}{r}-0.53 \\
0.0001\end{array}$ & $\begin{array}{r}-0.31 \\
0.0007\end{array}$ & $\begin{array}{r}-0.42 \\
0.0001\end{array}$ & $\begin{array}{r}0.06 \\
\mathrm{~ns}\end{array}$ & $\begin{array}{l}0.23 \\
0.02\end{array}$ & $\begin{array}{r}0.05 \\
\mathrm{~ns}\end{array}$ & $\begin{array}{r}-0.15 \\
n s\end{array}$ \\
\hline Tall fescue & $\begin{array}{r}0.00 \\
\mathrm{~ns}\end{array}$ & $\begin{array}{r}-0.15 \\
n s\end{array}$ & $\begin{array}{r}-0.08 \\
n s\end{array}$ & $\begin{array}{r}0.01 \\
\mathrm{~ns}\end{array}$ & $\begin{array}{r}-0.03 \\
n s\end{array}$ & $\begin{array}{l}-0.26 \\
0.004\end{array}$ & $\begin{array}{r}-0.19 \\
0.04\end{array}$ & $\begin{array}{r}-0.11 \\
n s\end{array}$ \\
\hline $\begin{array}{l}\text { White } \\
\text { clover }\end{array}$ & & $\begin{array}{r}-0.07 \\
n s\end{array}$ & $\begin{array}{r}0.07 \\
\mathrm{~ns}\end{array}$ & $\begin{array}{r}-0.10 \\
n s\end{array}$ & $\begin{array}{r}0.08 \\
\mathrm{~ns}\end{array}$ & $\begin{array}{l}-0.25 \\
0.003\end{array}$ & $\begin{array}{r}-0.19 \\
0.03\end{array}$ & $\begin{array}{l}0.24 \\
0.01\end{array}$ \\
\hline
\end{tabular}

1 Correlations of tall fescue and cocksfoot with other species were calculated from paddocks in which these species were sown. Correlations of white clover with other species were calculated from all paddocks.

pastures, $45 \%$ in cocksfoot, $50 \%$ in tall fescue). Both of these earlier studies used the same tiller method as the present study.

Highly significant $(\mathrm{P}<0.01)$ differences in the types of unsown grasses that were present were also evident. Annual grasses were stronger in South Island paddocks, while browntop and other perennial grasses (mainly sweet vernal, Yorkshire fog, Poa trivialis and crested dogstail) were stronger in North Island paddocks. Cocksfoot was slightly stronger in South Island paddocks (not significant at the 5\% level after adjusting for seed rates of sown species). However, cocksfoot was present as a volunteer species in 9 of 12 South Island "pure" tall fescue paddocks, which indicates its potential for success in that environment.

The most notable pattern shown by the correlations of tall fescue, cocksfoot and white clover with other species is the suppression of ryegrass, browntop and other perennial grasses by cocksfoot (Table 5). In the North Island, strong cocksfoot paddocks also had lower than average white clover content. The highest white clover presence was found in paddocks that had been invaded by volunteer perennial grass species. This association of high white clover with a low ratio of cocksfoot to volunteer grasses was not evident in South Island paddocks. 
In mixtures of tall fescue and cocksfoot, the correlation between the measures of presence of the two species was negligible (-0.04 in the North Island, -0.03 in the South Island). These correlations remained close to zero after partial covariance adjustment for seed rates of the two grasses. This indicates that variation in levels of tall fescue in these paddocks was not related to variation in the current strength of cocksfoot. However, tall fescue was stronger in paddocks where it was the only grass sown than in paddocks where it was mixed with cocksfoot. This difference could not be accounted for by differences in sowing rate of tall fescue.

\section{Association of pasture composition with soil fertility effects}

There were no significant correlations between fertiliser $\mathrm{P}, \mathrm{S}$ or $\mathrm{K}$ inputs and any pasture species. In the North Island, fertiliser $\mathrm{N}$ inputs were associated with increased cocksfoot $(\mathrm{r}=0.47, \mathrm{P}<0.01)$, decreased browntop $(\mathrm{r}=$ $-0.59, \mathrm{P}<0.001)$, and decreased white clover $(\mathrm{r}=-0.45$, $\mathrm{P}<0.01)$. In the South Island sample, no significant associations of pasture species with fertiliser $\mathrm{N}$ were evident.

Associations of species presence with soil nutrient levels were also more consistent in the North Island paddocks than in the South Island. In the North Island paddocks sown with cocksfoot, high soil $\mathrm{P}$ levels were correlated with strong cocksfoot $(\mathrm{r}=0.45, \mathrm{P}<0.01$, weak browntop $(\mathrm{r}=0.63, \mathrm{P}<0.001)$, reduced levels of other unsown perennial grasses $(\mathrm{r}=-0.52, \mathrm{P}<0.001)$ and reduced levels of white clover $(r=-41, P<0.05)$. Some of this association of soil $\mathrm{P}$ with cocksfoot dominance over white clover and low fertility grasses may be owing to fertiliser $\mathrm{N}$ inputs - that is, the high use of DAPbased products in the North Island. However, the positive correlations of cocksfoot with soil $\mathrm{P}$ and the negative correlations of browntop and other perennial grasses with soil $\mathrm{P}$ remained significant at $\mathrm{P}<0.05$ after adjusting for fertiliser $\mathrm{N}$ inputs. This suggests that high soil $\mathrm{P}$ had a direct effect on the competitive advantage of cocksfoot over other grasses.

The same pattern was not evident in South Island paddocks. Although South Island paddocks with high $\mathrm{P}$ levels had lower than average presence of unsown perennial grasses $(\mathrm{r}=-0.28, \mathrm{P}<0.05)$ and slightly more cocksfoot $(\mathrm{r}=0.24, \mathrm{P}=0.08)$, white clover was not affected $(\mathrm{r}=0.07, \mathrm{P}=0.59)$.

\section{Establishment effects}

The 37 North Island paddocks in this survey had previously been measured in 1991,1992, and 1994 using the same tiller coring method. Results from the 1996 measurements were compared with results obtained in November 1991 ( 8 months after sowing) to evaluate the importance of establishment effects on current species composition. Cocksfoot and volunteer grasses (ryegrass, browntop, other perennial grasses, and annual grasses) all increased significantly while tall fescue, legumes and flatweeds declined (Figure 1).

The association of 1991 measurements with 1996 measurements was particularly strong for tall fescue

Figure 1 Mean levels of main species recorded in 1991 and 1996 in 37 North Island paddocks.

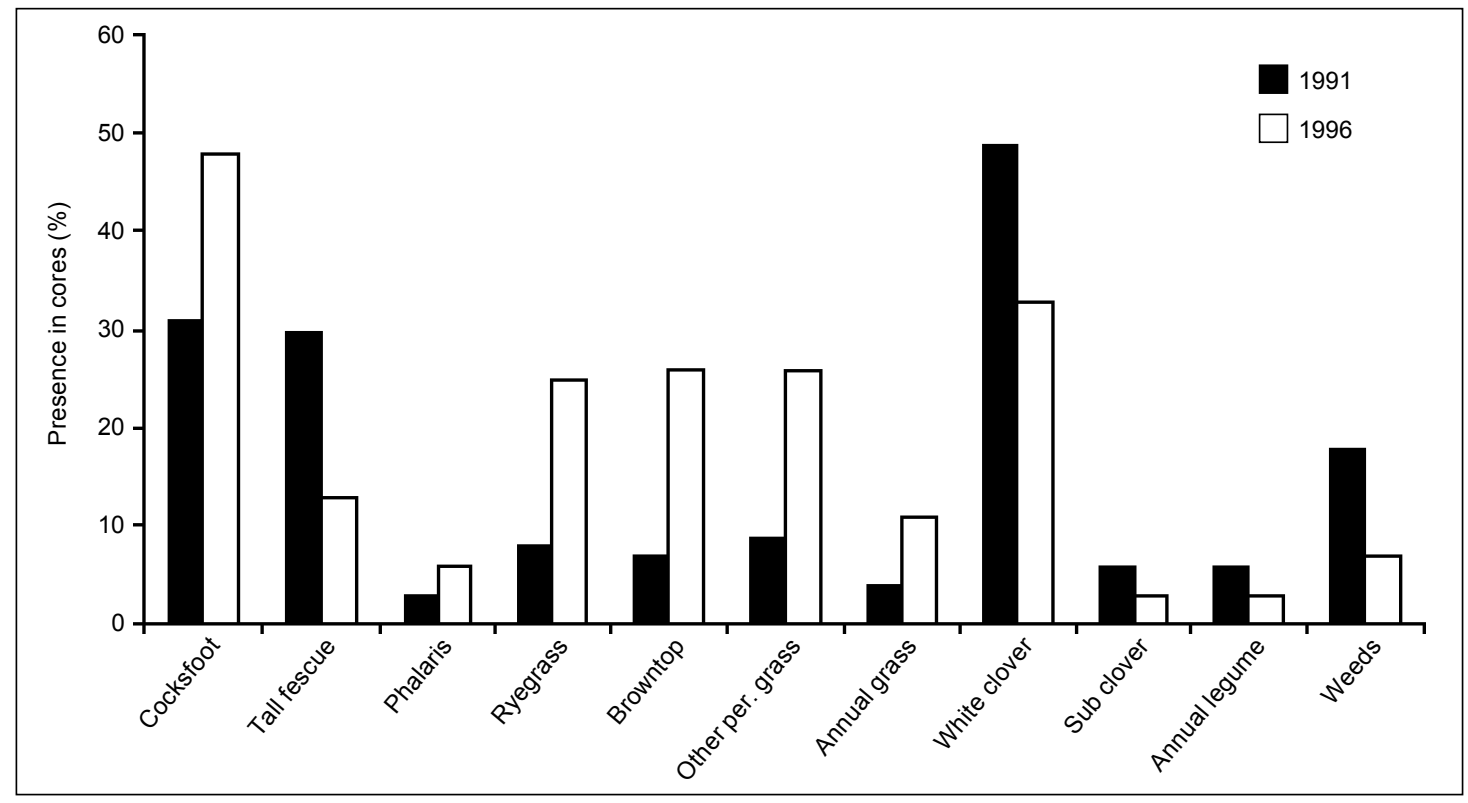


Table 6 Correlation coefficients of species incidence in 1996 in North Island survey paddocks with incidence in 1991. Second line in each cell is the significance level of the correlation coefficient.

\begin{tabular}{|c|c|c|c|c|c|c|c|}
\hline \multirow[b]{2}{*}{ Incidence in 1996} & \multirow{2}{*}{\multicolumn{2}{|c|}{ Cocksfoot $\quad$ Tall fescue }} & \multicolumn{3}{|c|}{ Correlation with incidence of species in cores in $1991^{1}$} & \multirow{2}{*}{ White clover } & \multirow{2}{*}{ Sub clover } \\
\hline & & & Ryegrass & Browntop & Other per grasses & & \\
\hline Cocksfoot & $\begin{array}{l}0.51 \\
0.002\end{array}$ & $\begin{array}{l}-0.33 \\
0.05\end{array}$ & $\begin{array}{l}-0.65 \\
0.0001\end{array}$ & $\begin{array}{l}-0.14 \\
\mathrm{~ns}\end{array}$ & $\begin{array}{l}-0.37 \\
0.03\end{array}$ & $\begin{array}{l}0.20 \\
\mathrm{~ns}\end{array}$ & $\begin{array}{l}0.03 \\
\mathrm{~ns}\end{array}$ \\
\hline Tall fescue & $\begin{array}{l}-0.41 \\
0.03\end{array}$ & $\begin{array}{l}0.68 \\
0.0001\end{array}$ & $\begin{array}{c}-0.20 \\
\mathrm{~ns}\end{array}$ & $\begin{array}{c}-0.21 \\
\mathrm{~ns}\end{array}$ & $\begin{array}{c}-0.14 \\
\mathrm{~ns}\end{array}$ & $\begin{array}{c}-0.40 \\
0.03\end{array}$ & $\begin{array}{c}-0.31 \\
\mathrm{~ns}\end{array}$ \\
\hline Ryegrass & $\begin{array}{l}-0.39 \\
0.02\end{array}$ & $\begin{array}{l}0.18 \\
\mathrm{~ns}\end{array}$ & $\begin{array}{c}0.56 \\
0.0003\end{array}$ & $\begin{array}{l}-0.08 \\
\mathrm{~ns}\end{array}$ & $\begin{array}{l}0.15 \\
\mathrm{~ns}\end{array}$ & $\begin{array}{c}-0.07 \\
\mathrm{~ns}\end{array}$ & $\begin{array}{l}-0.09 \\
\mathrm{~ns}\end{array}$ \\
\hline Browntop & $\begin{array}{c}-0.04 \\
\mathrm{~ns}\end{array}$ & $\begin{array}{c}0.04 \\
\text { ns }\end{array}$ & $\begin{array}{c}0.25 \\
\mathrm{~ns}\end{array}$ & $\begin{array}{l}0.55 \\
0.0005\end{array}$ & $\begin{array}{l}0.32 \\
0.05\end{array}$ & $\begin{array}{c}-0.17 \\
\mathrm{~ns}\end{array}$ & $\begin{array}{c}0.04 \\
\mathrm{~ns}\end{array}$ \\
\hline $\begin{array}{l}\text { Other } \\
\text { per grasses }\end{array}$ & $\begin{array}{l}-0.09 \\
\mathrm{~ns}\end{array}$ & $\begin{array}{c}0.22 \\
\mathrm{~ns}\end{array}$ & $\begin{array}{l}0.20 \\
\mathrm{~ns}\end{array}$ & $\begin{array}{l}0.05 \\
\text { ns }\end{array}$ & $\begin{array}{l}0.47 \\
0.003\end{array}$ & $\begin{array}{c}-0.24 \\
\mathrm{~ns}\end{array}$ & $\begin{array}{l}-0.06 \\
\mathrm{~ns}\end{array}$ \\
\hline $\begin{array}{l}\text { White } \\
\text { clover }\end{array}$ & $\begin{array}{c}-0.11 \\
\mathrm{~ns}\end{array}$ & $\begin{array}{c}-0.07 \\
n s\end{array}$ & $\begin{array}{l}0.32 \\
0.05\end{array}$ & $\begin{array}{c}0.03 \\
\mathrm{~ns}\end{array}$ & $\begin{array}{c}0.20 \\
\mathrm{~ns}\end{array}$ & $\begin{array}{c}0.08 \\
\text { ns }\end{array}$ & $\begin{array}{c}0.01 \\
\mathrm{~ns}\end{array}$ \\
\hline Sub clover & $\begin{array}{c}-0.05 \\
n s\end{array}$ & $\begin{array}{c}-0.02 \\
n s\end{array}$ & $\begin{array}{c}-0.01 \\
\mathrm{~ns}\end{array}$ & $\begin{array}{c}0.11 \\
\mathrm{~ns}\end{array}$ & $\begin{array}{c}-0.02 \\
n s\end{array}$ & $\begin{array}{c}-0.26 \\
\mathrm{~ns}\end{array}$ & $\begin{array}{l}0.70 \\
0.0001\end{array}$ \\
\hline
\end{tabular}

1 Correlations with tall fescue and cocksfoot were calculated from paddocks in which these species were sown. Correlations among other species were calculated from all paddocks.

(Table 6). However, the correlations were also moderately high for volunteer grasses such as browntop, ryegrass and other perennial grasses, indicating that early invasion of new pastures by these species can lead to long-term effects on pasture composition.

The negative association of 1996 tall fescue presence with 1991 white and annual clover presence suggests that a tall fescue sward that is "friendly" to these legumes during the early years is often a weak tall fescue sward.

The negative association of ryegrass in 1991 with cocksfoot in 1996 and the positive association of ryegrass with white clover suggest that, in east coast North Island environments, high content of ryegrass during the establishment period may reduce or delay cocksfoot suppression of white clover. These results suggest that ryegrass/cocksfoot seed mixtures may provide better balance of grass and clover than cocksfoot alone or tall fescue/cocksfoot mixtures Earlier survey results (Korte et al. 1991) indicated that in ryegrass/ cocksfoot mixtures, high rates $(>3 \mathrm{~kg} / \mathrm{ha})$ of cocksfoot in the seed mix had a negative long-term effect on ryegrass and white clover presence.

The good correlation of sub clover across years probably reflects the legacy of dry environments, with seed banks being built up before the establishment of these pastures. Other annual legumes also had a moderately strong correlation $(\mathrm{r}=0.70)$ across years. Although average levels of sub clover and other annual legumes have declined, they are still present in those paddocks in which they were recorded in 1991. In contrast, white clover presence showed little consistency across years.
A stepwise regression analysis was undertaken to see if soil fertility variables could explain any of the variation in pasture composition, after adjusting for establishment effects. After adjustment for pasture composition in 1991, current soil P levels were still positively associated with cocksfoot (partial $r=0.34$ ) and negatively associated with browntop (partial $\mathrm{r}=$ -0.44 ), other unsown perennial grasses (partial $r=-0.34$ ) and white clover (partial $r=-0.33$ ), with all coefficients significant at $\mathrm{P}<0.05$. After adjusting for establishment levels of tall fescue and cocksfoot, the factor most closely associated with tall fescue persistence was establishment levels of ryegrass (partial $r=-0.44$, $\mathrm{P}<0.05$ ).

\section{Conclusions}

Although cocksfoot tolerates low soil fertility, it responds to high fertility. This response has the desirable effect of suppressing low fertility grasses with poor productivity and quality (e.g., browntop, sweet vernal), but can also have the undesirable effect of suppressing clover and tall fescue.

Perennial ryegrass/cocksfoot seed mixtures may provide a more persistent balance of grass and clover than cocksfoot alone or tall fescue/cocksfoot mixtures.

Successful establishment of tall fescue is critical to its persistence. With better establishment practices and newer cultivars of tall fescue selected for seedling vigour, initial levels of tall fescue should improve, and soil fertility effects could then become important.

Persistence of balanced grass/clover pastures requires not only adequate soil fertility to support growth, 
but also suitable management of growth to prevent suppression of desirable species.

\section{ACKNOWLEDGEMENTS}

The study was funded by the Meat Research and Development Council of Meat NZ, Project 96 PR107/ 3.3.

\section{REFERENCES}

Korte, C.J.; Smith, D.; Slay, M.W.A.; Gray, M.; Quilter, S.J. 1991. Preliminary report on a survey of performance of drought tolerant pastures on East Coast sheep/beef farms. MAF Internal Report.

Ledgard, S.F.; Bier, G.J. 1993. Response to reapplication of phosphate fertilisers on hill pastures where fertilisers have been withheld for seven years. Proceedings of the New Zealand Grassland Association 55: 67-71.

Mitchell, K.J.; Glenday, A.C. 1958. The tiller population of pastures. New Zealand journal of agricultural research 3: 305-318.
Milne, G.D.; Moloney, S.C; Smith, D.R. 1993. Demonstration of dryland pasture species on 90 east coast farms. Proceedings of the New Zealand Grassland Association 55: 39-44.

Milne, G.; Fraser, T. 1990. Establishment of 1600 hectares of dryland species around Oamaru/Timaru. Proceedings of the New Zealand Grassland Association 52: 133-137.

Morton, J.D.; Korte, C.J.; Smith, D.R.; Watt, B.D.; Smith, R.G. 1993. Nitrogen use and farm performance on Wairarapa sheep and beef farms. Proceedings of the New Zealand Grassland Association 55: 53-58.

Smith, D.R.; Slay, M.W.A.; Gray, M.H.; Milne, G.D. 1993. On-farm establishment of drought-tolerant pastures on the east coast of the North Island. Proceedings of the New Zealand Grassland Association 55: 33-39. 